\title{
PLASMID FOR EXPRESSION OF APOPTIN IN Escherichia coli
}

\author{
Suyatmi', Tri Agusti Sholikah", Yoga Mulia Pratama², and Afiono Agung Prasetyo ${ }^{2,3,4^{*}}$
}

\footnotetext{
${ }^{1}$ Department of Histology Faculty of Medicine, Sebelas Maret University, JI. Ir. Sutami 36A, Surakarta, Indonesia.

${ }^{2}$ Biomedical Laboratory Faculty of Medicine, Sebelas Maret University, Jl. Ir. Sutami 36A, Surakarta, Indonesia.

${ }^{3}$ Center of Biotechnology and Biodiversity Research and Development, Sebelas Maret University, JI. Ir. Sutami 36A, Surakarta, Indonesia.

${ }^{4}$ Department of Microbiology Faculty of Medicine, Sebelas Maret University, Jl. Ir. Sutami 36A, Surakarta, Indonesia.

" Correspondence author: Afiono Agung Prasetyo, M.D., Ph.D. Department of Microbiology Faculty of Medicine, Sebelas Maret University JI. Ir. Sutami no 36A, Surakarta, Indonesia, Telp. 62-271-632489, Fax. 62-271-632489, E-mail: afieagp@yahoo.com; afie.agp.la@gmail.com
}

\begin{abstract}
The chicken anemia virus (CAV) Apoptin can induce apoptosis specifically in tumor cells and not in normal cells. Therefore, this shows a promising use for cancer gene therapy in the future. However, the mechanism of apoptin-induced apoptosis in tumor cells has not been well characterized. We tried to construct p-Ec-Apo (Apoptin expression plasmid for Escherichia coll) for further use, especially to explore the molecular aspect and therapeutically strategy of Apoptin. Aim of this study is to construct plasmid for expression of Apoptin in Escherichia coli. A complete open reading frame of the Apoptin gene of CAV/wild type was amplified by PCR. The PCR product was then purified from the agarose using QIAquick Gel Extraction Kit (Qiagen), subcloned into the respective sites of pETBlue-1 (Novagen). The molecular clone was transformed into Escherichia coli, purified, and sequenced. The nucleotide sequence was analyzed by CLC Main Workbench (CLC Bio). Results: The clone thus obtained, p-Ec-Apo, was successfully constructed.
\end{abstract}

Key words: Apoptin, Escherichia coli

\section{INTRODUCTION}

Apoptin is a protein that was originally identified from chicken anaemia virus (CAV), a virus from Gyrovirus genus, contains about 121 amino acid with $13.6 \mathrm{kD}$ in weight. Apoptin induces apoptosis specifically in tumour and transformed cells but not in normal cells. It resides in the cytoplasm of normal cells, but in cancer cells translocates into the nucleus (Peng et al., 2013). Apoptin-induced apoptosis has implicated various mechanisms. The mechanisms that are known such p53-independent pathway, inducing cell cycle G2/M phase arrest, and causing the nuclear accumulation of survival kinases. Therefore, apoptin promising for cancer gene theraphy in the future. However, other mechanism of Apoptin-induced apoptosis has not yet been well characterized, especially the mechanism of apoptosis that why without any side effects in normal cells. Last study reported that CDK1 may interacts with apoptin to modulate apoptosis in cancer (Zhao et al., 2013). It indicates that cellular signaling has implicate apoptin-induced apoptosis and this pathway has not yet been well studied. Using plasmid effector is very useful to develop apoptin as gene theraphy and to delineate mechanism of apoptin-induced apoptosis. To maximize expression of Apoptin, we sought to use plasmid effector which be suitable for Apoptin gene expression and that replicate at a high copy number. Therefore, we choose pETBlue-1 which be suitable for many application and its has high copy number (Novagen). In this study, we tried to construct p-Ec-Apo (Apoptin expression plasmid for Escherichia coll) for further use, especially to

ISSN 2413-0877 (C) 2015 The Authors.

Published by KnowledgeE Publishing Services This is an open access article under the CC BY-NC-ND license (http://creativecommons.org/licenses/by-nc-nd/4.0)

Selection and Peer-review under responsibility of the 3rd ICBS-2013

Doi http://dx.doi.org/10.18502/kls.v2i1.198 
explore the molecular aspect and therapeutically strategy of Apoptin.

\section{MATERIALS AND METHODS}

To construct an Apoptin expression plasmid, a complete open reading frame of the Apoptin gene of CAV/wild type (Prasetyo et al., 2009) was directly cloned by PCR using Accuprime Pfx DNA Polymerase (Invitrogen, Carlsbad, CA). The PCR product was checked by electrophoresis agarose, and then purified from agarose using QIAquick Gel Extraction Kit (Qiagen, Hilden, Germany). The PCR product was then ligated into the respective sites of pETBlue-1 (Novagen Darmstadt, Germany). The molecular clone then was transformed into NovaBlue Singles ${ }^{\text {TM }}$ Competent Cells (Escherichia coll) by heat shock, followed by carbenicillin resistant selection. Prior to growing colonies for plasmid isolation, the presence of the appropriate insert and its orientation was determined using direct colony PCR and restriction enzyme analyzed. After positive clones were identified, high-copy plasmids were isolated for transformation, restriction mapping, and sequence analysis. The sequencing step was performed in both orientations for confirmation, three times for each orientation. The nucleotide sequence was analyzed by CLC Main Workbench (CLC Bio).

\section{RESULTS AND DISCUSSION}

The mechanism apoptosis induced by Apoptin usually using Apoptin expression plasmid or Apoptin recombinant viral vector, mostly Adenovirus, for the best of our knowledge. For example, to rule out dependency of Apoptin to $\mathrm{Bcl}-2$ and $\mathrm{Bcl}-\mathrm{xL}$ proteins and the p53 pathway, was explored using human adenovirus vector (Li et al., 2013). A study explored the expression profiles of tumor-associated genes altered by Apoptin have also been done using Adenovirus vector (Wang et al., 2013). Other viral vector (e.g. lentiviral) was also reported been used (Ma et al., 2012). Eukaryotic Apoptin expression plasmid was also been used as tool to study the apoptosis induced by Apoptin (Zhan et al., 2012). Another strategy to study about Apoptin is using Apoptin-tagged with flag. For example, to explore the localization mechanism of Apoptin in human HepG2 tumor cell lines, the purified prokaryotic native His-apoptin was used as bait for capturing Apoptin-associated proteins (Peng et al., 2013). However, the data resulted from all strategy described previously may influenced by the vector and or tag used in the study. One may argue, that the best data to understanding the apoptosis mechanism of Apoptin in the cells should derived from "a pure Apoptin protein delivering into cells" experiments. To do so, adequate quality and quantity of Apoptin will be needed. Therefore, we tried to construct Escherichia coli expression plasmid for tumor research and or therapeutic applications. Efficient production of an engineered Apoptin in a recombinant Escherichia coli have been reported previously, however, the Apoptin was flagged with GST tag (Lee et al., 2012).

In results, an Apoptin recombinant plasmid to express wild type of Apoptin in Escherichia coliexpression system, namely as $\mathrm{p}$-Ec-Apo, was successfully constructed. The plasmid expressor, pETBlue-1, has T7lacpromoter and its originated from pET plasmid expressor which has high copy number. $\mathrm{pET}$ was included in best-developed class of plasmid vectors for many manipulations is based on the colicin $\mathrm{E} 1$ (ColE) replicon. In other yield, pUC origin of replication in $\mathrm{pETBlue}-1$ provides an advantage for plasmid manipulation. It may be very 
benefically for $p$-Ec-Apo because it has high copy number and providing other plasmid manipulation. Plasmid manipulation may contribute in apoptin modification which helpful to delineate mechanism of Apoptin-induced apoptosis and to explore the molecular aspect of Apoptin. In conclusion, $\mathrm{p}$-Ec-Apo was successfully constructed which originated from $\mathrm{pETBlue-}$ 1 that has high copy number and its has advantages in plasmid manipulation.

\section{ACKNOWLEDGMENT}

This work was supported partially by grants from from APBN/DIPA UNS (No. 267a/ UN27.16/PN/2013 and 6139a/UN27.16/PN/2013).

\section{REFERENCES}

Lee, M.S., F.C. Sun, C.H. Huang, Y.Y. Lien, S.H. Feng, G.H. Lai, M.S. Lee, J. Chao, H.J. Chen, J.T. Tzen, and H.Y. Cheng. 2012. Efficient production of an engineered apoptin from chicken anemia virus in a recombinant $\mathrm{E}$. coli for tumor therapeutic applications. BMC Biotechnol, vol. 12:27.

Li, Q., H. Zhang, C. Tan, W. Peng, G. Ren, B. Jia, Y. He, P. Wang, X. Zhou, and T. Xiang. 2013. AdHu5-apoptin induces G2/M arrest and apoptosis in p53-mutated human gastric cancer SGC-7901 cells. Tumour Biol, 2013 Jun 28. [Epub ahead of print]

Ma, J.L., S.X. Han, J. Zhao, D. Zhang, L. Wang, Y.D. Li, and Q. Zhu. 2012. Systemic delivery of lentivirus-mediated secretable TAT-apoptin eradicates hepatocellular carcinoma xenografts in nude mice. Int J Oncol, vol. 41:1013-1020.

Peng, C., P. Yang, Y. Cui, M. He, L. Liang, and Y. Di. 2013. HSPA9 overexpression inhibits apoptin-induced apoptosis in the HepG2 cell line. Oncol Rep, vol. 29:2431-2437.

Prasetyo, A.A., T. Kamahora, A. Kuroishi, K. Murakami, and S. Hino. 2009. Replication of chicken anemia virus (CAV) requires apoptin and is complemented by VP3 of human torque teno virus (TTV). Virology, vol. 385:85-92.

Wang, C., W. Wang, J. Wang, H. Zhan, L. Jiang, R. Yan, Z. Hou, H. Zhu, L. Yu, Y. Shi, M. Ding, and C. Ke. 2013. Apoptin induces apoptosis in nude mice allograft model of human bladder cancer by altering multiple bladder tumor-associated gene expression profiles. Tumour Biol, vol. 34:1667-1678.

Zhan, H., J.S. Wang, H.F. Wang, Y.G. Zuo, C.H. Wang, and M.X. Ding. 2012. Apoptin induces apoptosis in human bladder cancer EJ and BIU-87 cells. Asian Pac J Cancer Prev. vol. 13:135-138.

Zhao, J., S.X. Han, J.L. Ma, X. Ying, P. Liu, J. Li, L. Wang, Y. Zhang, J. Ma, L. Zhang, and Q. Zhu. 2013. The role of CDK1 in apoptin-induced apoptosis in hepatocellular carcinoma cells. Oncol Rep, vol. 30:253-259. 